\title{
Scientific contributions of the first female chemists at the University of Vienna mirrored in publications in Chemical Monthly 1902-1919
}

\author{
Rudolf Werner Soukup ${ }^{1}$ (D) $\cdot$ Robert Rosner $^{1}$
}

Received: 29 November 2018 / Accepted: 1 March 2019 / Published online: 29 April 2019

(c) The Author(s) 2019

\begin{abstract}
In 1897, the first female students were admitted at the Faculty of Philosophy at Vienna University. The first dissertation in chemistry was approved in 1902. In the following years, only one or two women were annually enrolled, while the number of male students of chemistry continuously fluctuated around 22. Whereas four women completed their doctorate in the first year of WWI, six followed in 1917, and ten more in 1919. Strikingly, in that year the number of female students even exceeded that of male colleagues. Margarethe Furcht, the daughter of a Jewish stockbroker, was the first female chemist with a doctoral degree certificate in the Austro-Hungarian Empire. Her paper "Über die Veresterung von Sulfosäuren...", which she published in 1902 together with her academic supervisor Rudolf Wegscheider, was one of the first scientific chemical publications of women in Austria. However, of all female graduates, only a small number worked as chemists within the next two decades. After the occupation of Austria by German Troops in March 1938, seven of the Jewish women managed to emigrate, four were murdered in the Holocaust. Given the importance of this period within the landscape of European scientific history, we here aim to provide the first comprehensive overview of the history of women studying chemistry at the University of Vienna.
\end{abstract}

\section{Graphical abstract}

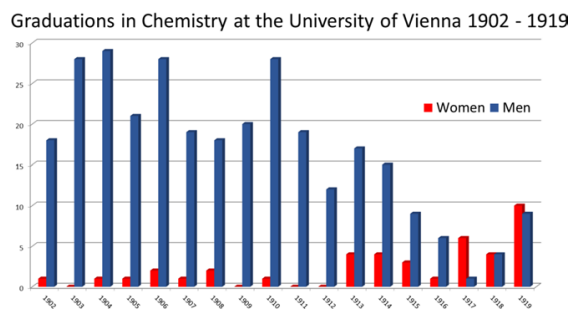

Keywords Austrian female chemists · Shoah victims · University of Vienna

\section{Introduction}

In September 2018, the European Society for History of Science (ESHS) held a symposium entitled "A long way of women's integration into scientific community". When we are speaking about women studying in the former Austrian

Rudolf Werner Soukup

rudolf.werner@kabelnet.at

1 Institute of Inorganic Chemistry, Functional Materials, University of Vienna, Vienna, Austria
Empire, the way of women's integration into the scientific community was not only very long, but far longer than in other European countries. As a matter of fact, women were even hindered from starting walking this way.

Looking back to medieval times or to the Early Modern Age, we can find women alchemists in Austria and the Crown Lands of the Habsburg Monarchy, especially in Bohemia: Barbara von Cilli is known for fraudulent forgery of coins in Mělník around 1441. At the end of the sixteenth century, Salomena Scheinpfluger performed alchemical experiments at the castle of the Bohemian magnate Wilhelm von Rosenberg in Wittingau (today Třeboň in the 
Czech Republic). Barbara von Oettingen was working at the famous laboratory of Emperor Rudolf II at the Hradschin in Prague. Finally, one should not forget that-according to investigations on the bones-the founder of chemistry in the service of medicine Theophrast of Hohenheim (better known as Paracelsus) most likely was a woman $[1,2]$. But no female chemists stepped in appearance in the seventeenth, eighteenth, and the early nineteenth century. In Robert Rosner's monograph "Chemistry in Austria 1740-1914" not a single female chemist is mentioned.

\section{The first hesitant steps}

Since 1844, Professor Anton Schrötter had held public lessons at the Polytechnic Institute in Vienna. It is known that in 1849 and 1850, some Viennese women attended these lessons [3]. But the first chemical experiment by a female researcher was carried out by a woman from Russia: from October 1870 to April 1871, Maria Mikhailovna Manaseina, née Korkunova (1841-1903), from St. Petersburg performed experiments in the laboratory of Prof. Julius Wiesner at the Polytechnic Institute in Vienna. There, she carried out her research on alcoholic fermentation in yeast $[4,5]$. She delivered an experimental proof for cell-free alcoholic fermentation. In a letter to Emil Erlenmeyer, she asked the famous chemist in Heidelberg to publish her work in Liebig's Annalen. But Erlenmeyer refused. So, after her return to St. Petersburg in 1871, she immediately published a paperfirst in Russian [6, 7], and a few months later in German (the German one in "Wiesner's Mikroskopische Untersuchungen" [8]). In 1897 [9] and in 1898 [10], she pointed out her priority over the later Nobel laureate Eduard Buchner [11].

Women were admitted to a regular study at the Polytechnic Institute Vienna (since 1872 called "Technische Hochschule") only in 1919. Wenzel Robert Count von Kaunitz-member of the Czech National Liberal Party in the parliament in Vienna-stated in 1895: "Of all the states of the earth today only Austria and Germany are still defending their point of view that they want to exclude the female youth from university study. Wherever humanitarian and scientific progress is concerned, we always come last" [12]. One has to take into account that at the University of Zurich, for example, far more than 100 women had studied medicine until the summer term of 1873 [13].

Only around 1872, a narrow window opened. Hermine Findenigg and Henriette von Aigentler (1854-1938) were allowed to listen to some pharmacological lectures and to participate in the chemical laboratory as irregular students at the Karl-Franzens-University Graz. However, this opportunity ended again in 1876 [14].

A milestone in the women's struggle for university access was the graduation of Dr. med. Gabriele Possanner von Ehrenthal (1860-1940) on 2 April 1897 in the great festival hall of the University of Vienna. A few months later, Margaret(h)e Hönigsberg (married Hilferding) would become the first woman to be admitted to study chemistry at the Faculty of Philosophy [12] (chemistry was part of the Faculty of Philosophy at the Viennese University since 1849). However, Hönigsberg was admitted only as an irregular student, although she had passed the "Matura" admission examination. In the winter semester of 1900/1901, when women were officially allowed to study at the Faculty of Medicine, she moved to the Medical Faculty [15]. After completing her studies, she worked in the Association for Individual Psychology. At the beginning of the Second World War she worked at the Vienna Rothschild Hospital under the direction of Prof. Viktor Frankl. Deported to the Concentration Camp and Ghetto Theresienstadt in June 1942, she died in September of the same year when she was transported to Concentration Camp Treblinka [16].

Due to the delayed development of women's access to Austrian universities, it is not surprising that the first female author of a scientific publication on a chemical topic in the most prominent Austrian journal "Monatshefte für Chemie" was a woman from abroad. In December 1901, a paper by Dr. Agnes Kelly [17] from Adelaide, Australia—coauthored by Dr. Sigmund Fraenkel—about the constitution of chitin was presented in a session of the Austrian Academy of Science and printed in the "Monatshefte für Chemie", vol. 23 $[18] .{ }^{1}$

\section{Margarethe Furcht: the first graduated female chemist in Austria}

The first female dissertation in chemistry was approved in 1902 [19]. Margarethe Furcht-born in Vienna on 10 November 1879 as the daughter of a Jewish

\footnotetext{
1 Agnes Murgoci, née Kelly was born in South Australia on 28 March 1874 as the daughter of Scottish emigrants. When Agnes was 2 years old, her mother returned with her to Scotland. Agnes received her education at the Scottish Dollar Academy, founded in 1818, in the Council Area Clackmannanshire, and then studied zoology at Bedford College for Women in London. In 1900, when Agnes Kelly went to Munich, where she and her fellow student Marie Stopes were the first women to receive a $\mathrm{PhD}$. In Munich, she worked at the Institute of Mineralogy under Prof. Paul Heinrich Groth. In 1901, she performed experiments at the II. Chemical Institute in Vienna. In 1904, she worked at the Institute of Physiochemical Chemistry in Strasbourg. In November 1904, she married the Romanian Professor of Mineralogy and Geology George Munteanu Murgoci (1872-1925). After a short stay in California, the couple went to Bucharest. During the First World War, she fled with her children (Helen and Radu) via Russia and Norway to Bristol in England. In May 1929, she was so badly injured in an accident on the Isle of Wight that she died a few days thereafter.
} 
stockbroker-was the first female chemist who graduated with $\mathrm{PhD}$ in the Austro-Hungarian Empire. Her paper "Über die Esterbildung von aromatischen Sulfosäuren”, published in 1902 (together with her academic supervisor Prof. Rudolf Wegscheider) [20], was the second scientific chemical publication by a female author in the "Monatshefte für Chemie". After her graduation on 19 July 1902 she worked at the "Technologische Gewerbemuseum". Sie published papers on silver salts of levulinic acid [21], on innovations in the soap industry, and on developments in the field of modern explosives. In the early 1930s, Dr. Furcht was employed at the Viennese factory Gustav Ganz \& Co. There, she was engaged in the improvement of radio tubes, in particular so-called "high-voltage cathode tubes" of the OSTAR type. Following the occupation of Austria by German troops in March 1938, Margarethe Furcht immigrated to England and worked as an industrial chemist in London. She died at the age of 96 years on 12 February 1976 in London [22].

\section{Some statistics}

Over the next few years, only one or two women were enrolled annually, while the number of male students of chemistry continuously fluctuated around 22 . This is a percentage of about $5 \%$. Whereas four women completed their doctorates in the first year of WWI, six followed in 1917, and ten more in 1919. Strikingly, in that year the number of female students even exceeded that of male colleagues. Thereafter, the percentage declined again continuously to about $7 \%$ until 1933 .

Now, a comment on the birth places of those women, who obtained a doctorate in chemistry at the University of Vienna between 1900 and 1919: Most of them (15) came from Vienna, 7 from Galicia (which today forms part of Ukraine), 3 from Bukovina, 5 from Moravia, 2 from Bohemia, 1 from Slovenia, 2 from Styria, 3 from Lower Austria, 1 from Upper Austria, and 1 from Poland [23], which was part of Russia at that time. Until 1919, the total number of all female chemists who graduated from the University of Vienna was 40 [24]. For about half of them, the authors succeeded to gather information about their later life. Critically, some of these women changed their name after marriage, which complicates research on their life course. The documents of the final examinations (the "Rigorosenakten" [25]) and the personnel files (the "Personalakten") at the Archive of the University of Vienna and the Archive of the Technical University were taken into account for this report, whereas older data were based mainly on the "Nationale". Additionally, publications from the two chemical institutes of the Viennese University were sourced and Internet research performed. One sad truth is the fact that many names of these women can be found in the Central Database of Shoah Victims' Names "Yad Vashem" in Jerusalem.

The disproportionate share of Jewish female students among the doctoral candidates is remarkable: $50 \%$ of the female chemistry students who were candidates for a $\mathrm{PhD}$ at Vienna University were Jewish, while in the Habsburg monarchy the overall proportion of Jews was about $4 \%$. The reason for this is not only the exodus of the Jewish population from Galicia which was a frontline area already in the first year of WWI, but also the high esteem of academic education among the Jewish community. In 1910, there were only two girls' high schools in Vienna that offered graduation with a "Matura"- which was required for university studies. In Salzburg there was one, but in Styria and all the other alpine countries of Austria none. By contrast, in Galicia, where many Jews lived, there were already 15 such high schools [26].

How was the life of such a Jewish woman, who earned her PhD just before WWI?

\section{Susi Glaubach: the first Austrian female pharmacologist}

Susi Glaubach was born 5 September 1893 in Czernowitz, capital of Bukovina in the Austrian-Hungarian Monarchy. Her Jewish father was a solicitor, i.e., an assistant to a lawyer. From 1913 on, Susi Glaubach studied chemistry at the University of Vienna. She wrote her doctoral thesis "Über die Oxidation von 1,4- und 1,5-Oxyden" in 1916 and earned her doctoral degree on 28 June 1917. The results of her experiments performed at the laboratory of the IInd Chemical Institute were published in 1922 by Adolf Franke and Fritz Lieben [27]. Importantly, it was a common practice in those days to acknowledge the work of students only in the experimental section of a paper.

In 1922, Susi Glaubach worked on the formation of glycerol during alcoholic fermentation and coauthored a paper on this topic together with the famous Swiss physiological chemist Emil Abderhalden. In 1923, she studied the production of insulin together with Prof. Ernst Pick. Two years later, she was hired at the Pharmacologic Institute of the Viennese University, where she worked on cyanamide poisoning, the influence of temperature regulation by the thyroid hormone thyroxine and the hormonal regulation of urinary excretion.

In 1938, Susi Glaubach immigrated to the USA. There, she found employment at Newark Beth Israel Hospital and published numerous papers on physiological-chemical topics between 1939 and 1954. She died on 11 August 1964 in Princeton, New Jersey [28]. 


\section{Rosa Stern: pioneer of spot test analysis}

Susi Glaubach's fellow student Rosa Stern finished her thesis "Über das Propan-1,3-phenyl-2,2-methyläthyl und Derivate" in 1914 during her 10th semester. She was the daughter of the merchant Julius Stern, born on 5 March 1891 in Vienna. Following her graduation on July 22, 1914 - 6 days before the outbreak of WWI-she stayed at the chemical institute and stayed together with the chemist Fritz Feigl. In 1921, Feigl and Stern published the first comprehensive paper on spot test analysis [29]. This pioneering work was initially dismissed as a gimmick until analytical chemists like Wilhelm Schlenk, Robert Strebinger, or Georg Vortmann gave encouraging comments on working with reagents in droplet quantities.

During the following years, Dr. Rosa Stern was employed as a chemist at a Viennese company. In the course of this employment, Stern and Leo Krammer of the "Hauser and Sobotka Malzfabrik Wien-Stadlau" became patent holder for processes regarding the preparation of diastase preparations [30]. In a "Property Notice" dated June 1938, she discloses two protected and two non-protected inventions [31]. Nevertheless, she published several papers of purely scientific interest [32].

On December 10, 1938, an advertisement appeared in the Australian newspaper "The Age": "Specialist in Baking and Cereal Chemistry, Enzymology, Food Chemistry, Viennese lady Dr. Sc., 24 years experience in leading Austrian firm, five languages, desires employment. Dr. Rosa Stern, Vienna VII., Westbahnstraße 60.” In April 1939, Dr. Stern immigrated first to London [33] and from there to New Zealand. In 1940, the New Zealand Department of Science and Industry in Christchurch reported that at the Wheat Research Institute "The position of Junior Chemist was filled by the appointment of Dr. Phil. Rosa Stern, of Vienna, who has had a wide experience of cereal chemistry." At that institution, Rosa Stern published numerous scientific studies. She died on 9 August 1962 and was buried at Linwood Cemetery in Christchurch, New Zealand.

\section{Lily (Lilli) Stern (married Bader) immigrated via England to the USA}

Lily Stern was born on 22 August 1893 in Vienna (registered under the name Lillian Margarethe Stern) as the daughter of Philo Stern and his wife Regine, née Mayer. The father was an insurance inspector in Teplitz in Northern Bohemia (now Teplice). His daughter described him as "brilliant," "well-read," and "educated," "expert of commerce and trade in the Austrian Monarchy"; however,

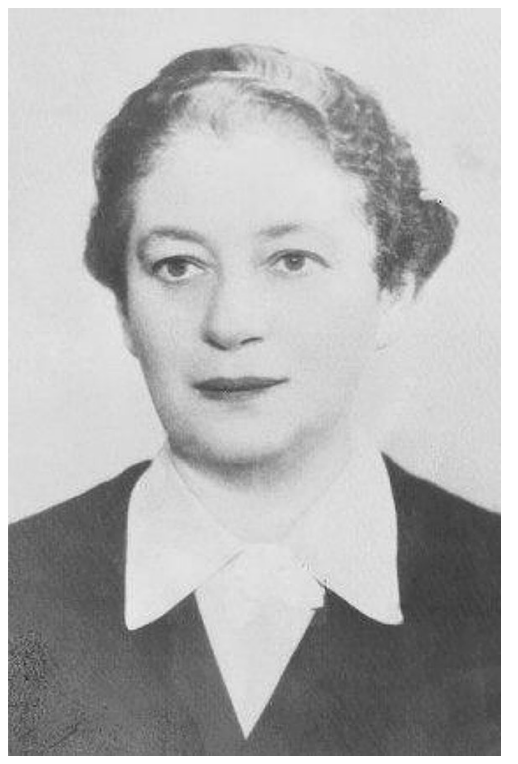

Fig. 1 Lily Stern. Source: Katharina Kniefacz, "Lillian (Lily) Margarete Bader (geb. Stern): In: Gedenkbuch für die Opfer des Nationalsozialismus an der Universität Wien 1938

she also called him "choleric" in another passage of the same manuscript, which was later deleted. Due to an unfortunate speculation, Philo Stern lost the dowry of his wife. From that time on, Lily's mother earned a living as a piano teacher. Lily grew up with her older sister Hilda (1889-1957, married Parker resp. Pollak), at first in Teplitz and then in Vienna. In 1903, her mother, together with her sister-in-law Julie, took over the management of the "Stern'sche Mädchen-Lehr- und Erziehungsanstalt" in Vienna I., Werdertorgasse 12-14, which was founded in 1868 by some relatives. This "Stern'sche Mädchenpensionat" was the first school to provide higher education for girls in Vienna (Fig. 1).

In 1913, Lily began to study German at the University of Vienna, but switched a year later to chemistry, because she was fed up with the dreariness of literary lectures. She describes the atmosphere at the laboratory as friendly and companionable. During the laboratory exercises, serious accidents occurred. A fellow student broke the distillation flask during the distillation of acetic acid. The acid ran down her face, even into her lungs. She survived, but her eyes were beyond saving, she went blind. Another colleague killed herself with potassium cyanide [34-41]. In her memoirs, Lily Stern mentions also her fellow student Nelly Kövesdy (married Călţun, married Grozăvescu), who was expelled from the university because of illegal gathering of analysis results. In 1927, this lady became infamous: She shot her second husband, the well-known singer Trajan Grozăvescu. Surprisingly, the court decided to acquit her-which is discussed until today as a classic 
trial jury misjudgment in advanced tutorial classes on jurisdiction.

When Lily Stern started to write her PhD thesis in the 4th year of WWI, she became an assistant, which freed her from all charges. Her task was to supervise the laboratory work of 60 officers on leave. The most gifted of them was the young and highly decorated Lieutenant Hermann Mark (erroneously indicated in the typescript as "William Mark"), who later became famous for his contributions to the development of polymer science.

In the summer of 1919, Lily Stern finished her studies under Professor Ernst Zerner (1884-1966), who had returned from the war, seriously injured, with the dissertation "Über den Aufbau der Stearinsäure und zur Kenntnis der Cholsäure". She also passed the state examination for piano teachers. Her teacher in theory was the composer Hans Gál (1890-1987). In 1918, she married Dr. Edwin Bader (born 1891 in Pohrlitz near Nikolsburg in Moravia (today Pohořelice)—died 1973 in New York). With Edwin she had two daughters: Hannah and Dorit.

In 1919, Dr. Lily Bader became assistant at the "Staatliche Lehr- und Versuchsanstalt für Chemische Industrie und Gewerbe", founded in 1910 in Vienna XVII, but a year later, she took over the directorship of the Stern'sche Pensionat. The annexation of Austria in March 1938 led to the aryanization of the Stern'sche Schule. In August 1938, the family flew from Vienna to London, where Lily first worked as a maid. In London's Hyde Park, Lily Bader happened to meet her doctoral supervisor Prof. Ernst Zerner, who was engaged in a research assignment for a large company. Dr. Zerner succeeded in employing her as his assistant and to provide a job for her husband. Meanwhile her daughter Hannah sewed soldier's uniforms. All of this was illegal because no one in the family had a work permit in the UK. In August 1940, Erwin and Lily Bader travelled with the ocean liner "S.S. Antonia" from Liverpool to Canada and from there to the USA. Since her husband initially could not work in his profession, Lily gave lessons as a piano teacher. After Edwin Bader had received admission as a physician in the USA, Lily became his receptionist. She died on 13 February 1959 in New York [42, 43].

\section{Martha Cornelius (Kohn, married Fodor), chemist in Zagreb, victim of the Holocaust}

Martha Kohn-her family name was later changed to Cornelius-was born on 21 June 1893 in Vienna. For her dissertation "Zur Kenntnis des Aminoäthylalkohols und seiner Derivate", Martha carried out experiments at the laboratory of the Ludwig-Spiegler-Foundation in Vienna VIII., Alserstraße 53. This work was published together with the

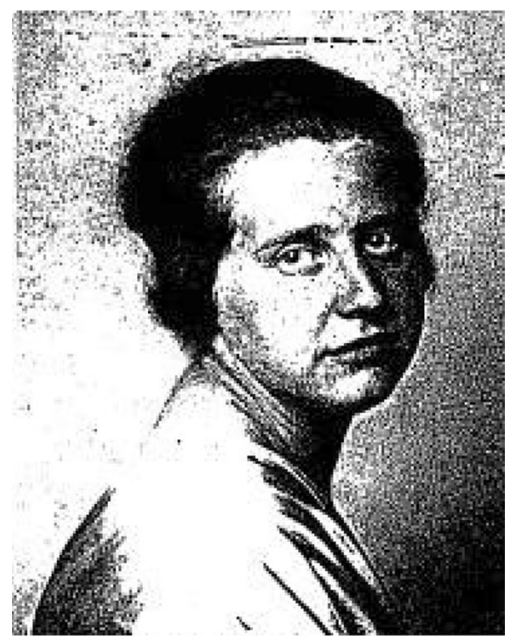

Fig. 2 Dr. Martha Fodor, née Cornelius (Kohn), Yad Vashem databank

physiochemist Sigmund Fraenkel (1868-1939) [44]. She received her PhD on 5 February 1918 (Fig. 2).

A few years later, Martha Cornelius married the chemist Dr. Otto Fodor (1890-1941), alumnus of the Technische Hochschule in Berlin, with whom she had a daughter named Aliza Beserglik Fodor. Before WWII, Dr. Martha Fodor was employed as a chemist in Zagreb. Her husband worked in Belgrade, also as a chemist. It was after the invasion of the Deutsche Wehrmacht in Zagreb on April 10, 1941, that she was deported to "Hruscica" (most probably the Kruščica Concentration Camp near Vitez in central Bosnia) and finally to the infamous women's Concentration Camp Loborgrad [45]. In August 1942, she was deported from Loborgrad to Auschwitz, where she was murdered. Her husband, who was in the possession of a US Patent for the preparation of an anhydride of salicylic acid [46], was deported from Belgrade to an unknown concentration camp in 1941 [47].

\section{Käthe Baron (married Leipelt), victim of the Nazi regime in connection with the sixth leaflet of the "White Rose"}

Käthe (Katherina) Baron was born on 28 May 1893 in Boskowitz in Moravia (today Boskovice in the Czech Republic). Her mother was Hermine Baron, née Löw, born in 1866 in Cerná Hora near Brno and deported on July 19, 1942, to Theresienstadt. Her father, Arnold Baron (died 1942 in Brno), was a civil servant in Vienna [48]. Käthe received her doctorate in 1917, with her thesis entitled "Über die Einwirkung von Schwefelsäure auf ein ditertiäres Diol" (Fig. 3).

After WWI, she married Dipl. Ing. Konrad Leipelt (born in 1886) from Neisse an der Oder. In 1921, their son Hans 


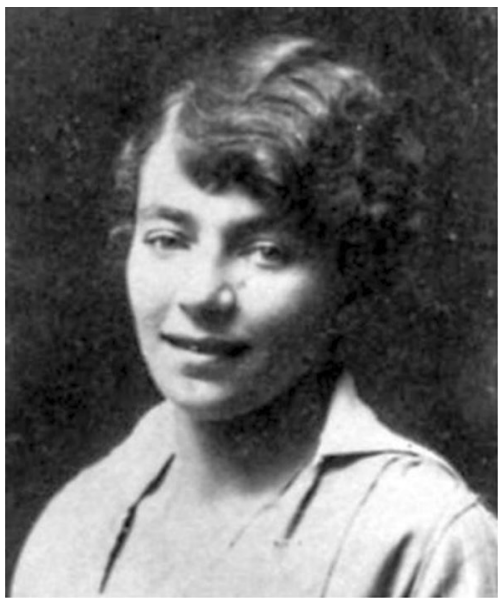

Fig. 3 Katharina Leipelt, née. Baron, January 1920. https://de.wikip edia.org/wiki/Katharina_Leipelt\#/media/File:Katharina_Leipe 1t_1920.jpg. Accessed 2 November 2018

was born (in Vienna), and 4 years later their daughter Maria (in Hamburg-Eppendorf-as the family had meanwhile moved to the Elbe). Konrad Leipelt had first found employment with the "Norddeutsche Affinerie" (today: "Aurubis") before becoming Technical Director of the "Zinnwerke Wilhelmsburg". In 1932, the Leipelts moved to the village Rönneburg on the southeastern outskirts of Harburg. One year later, Käthe Leipelt and her family were affected by the provisions of the Nuremberg Laws. Her children Hans and Maria Leipelt were considered "half Jewish". Nevertheless, Hans Leipelt volunteered for military service. As an infantryman he participated first in Poland and half a year later in the campaign in France. In June 1940, he was awarded the Iron Cross IInd Class. Soon afterward, he was dishonorably discharged from the "Wehrmacht". His father was able to arrange a place to study chemistry for him at the University of Hamburg. In the winter term of 1941/1942, Hans Leipelt moved to Munich to the institute of Professor Heinrich Wieland, who helped several racially persecuted people.

When Konrad Leipelt surprisingly suffered a fatal heart attack in September 1942, the family was deprived of the last protection against the anti-Semitic attacks of the Nazi state. Käthe Leipelt became a forced laborer at a fodder company in Harburg. One morning in February 1943, Hans Leipelt found a leaflet addressed to the Munich students in his mail: the sixth leaflet of the "White Rose". He took it to the laboratory and showed it to his colleague, Marie-Luise Jahn. She remembers this moment very well after 60 years: "Together we read the leaflet and were amazed that someone had the courage to say what we thought but never dared to write. We were impressed." Both did not know who was responsible for the content. Only after the siblings Scholl and Christoph Probst were arrested on 18 February 1943 and sentenced to death 4 days later, they knew who had spread this call for resistance. Marie-Luise Jahn retrospectively described her reaction: "We had the leaflet, but those who wrote it had been executed by the Nazis, ... we decided we must go on, we did not think about the danger." Hans Leipelt and Marie-Luise Jahn copied the leaflet several times with a portable typewriter and provided all copies with the addition “And their spirit still lives!” In October 1943, Hans Leipelt and Marie-Luise Jahn were denounced and arrested. Käthe Leipelt immediately traveled to Munich to organize help for her son. On 7 December 1943, Käthe Leipelt was arrested herself and imprisoned in the Fuhlsbüttel police prison. Two days later, she was found dead in her cell. The indictment of Hans Leipelt, Marie-Luise Jahn and seven other Munich friends was "preparation for high treason in coincidence with enemy favoritism and broadcasting crimes". The trial before the 2nd Senate of the People's Court took place on 13 October 1944 in Donauwörth. Hans Leipelt was sentenced to death and executed on 29 February 1945 . The sentence for his sister was 12 years in prison. In April 1945, Maria Leipelt was freed by the US Army. Maria Leipelt-Bade became biochemist and college professor at the Biology Department at Boston College. She died in September 2008 in Concord, Massachusetts [49].

\section{Marianne Richter-Quittner: a forgotten pioneer of physiological chemistry}

Marianne Quittner, daughter of Albert Quittner (1861-1916) and Irma Quittner, née Grünwald, was born in Vienna on 22 January 1893. She passed the Matura examination in 1912. Her thesis "Über Methylierung der Eiweißstoffe" was accepted by Prof. Wegscheider and Prof. Schlenk in 1917. She earned her doctorate on 18 July 1918. As became obvious retrospectively, the Nobel laureate of 1930, Karl Landsteiner, used her experimental results when he was chief dissector at the Wilhelminenspital [50]. ${ }^{2}$ As of 1919, Marianne Quittner published papers on blood chemistry together with Prof. Wilhelm Falta (1875-1950), who was at that time primarius at the Kaiserin-Elisabeth-Spital. After her marriage (in 1919?), her family name became Richter-Quittner. She furthermore published a paper on diabetes with Karl Hitzenberger (1893-1941) of the I. Medizinische Universitätsklinik in 1921 [51]. Other fields of her research were the purine metabolism, the cholesterol degradation, and the effect of heavy metal salts. In 1923, Marianne Richter-Quittner determined the chemical components of the cerebrospinal fluid together with Franz Depisch [52]. In late 1923, she stayed

\footnotetext{
2 Josef Herzig and Karl Landsteiner report that the experimental results in the paper "Über die Methylierung der Eiweißstoffe" were achieved by Miss Marianne Quittner and Mr. F. Zipperer.
} 
at the chemical laboratory of Clinique Médicale B (Dozent Léon Blum) in Straßburg, where she worked on blood transmineralisation. The experimental results obtained during this stay were reported in October 1924, when she gave a talk at the Wiener Biologische Gesellschaft [53]. Marianne Richter-Quittner died on January 21, 1931 in Vienna [54].

\section{Erna Demelius (married Machon) became an industrial chemist in Chemnitz}

Erna Demelius was born in Vienna on 14 January 1896. Her father was the rector of the University of Innsbruck, Prof. Ernst Demelius (1859-1904), who died in a tragic climbing accident on the Obergabelhorn in Switzerland in 1904 [55]. Paula Demelius, née Baroness Bach (1862-1923), was her mother: a botanist and author of several scientific papers [56]. After a 5-year study at the University of Vienna, Erna Demelius finished her dissertation "Über das Cholesterol" in 1919.

Following her marriage, her name changed to Dr. Erna Machon. In the early 1940s, Dr. Machon obviously was employed at the Boehme Fettchemie GmbH in Chemnitz, during which time two patents were registered under the name of her and her colleague Dr. Friedrich Schmitt: DE 749079C "Process for the production of leather lubricants" and DE 747487C "Process for degreasing hides and skins".

\section{Female coworkers of Prof. Wilhelm Schlenk, the famous investigator of free radicals}

Wilhelm Schlenk (1879-1943), discoverer of organolithium and organomagnesium compounds and investigator of free radicals, was professor at the IInd Chemical Institute of the University of Vienna from 1916 to 1921 . He had several female students:

Rautgundis (Raudgundis) Gertrud Rotter was born in Mährisch-Schönberg (today Šumperk, Czech Republic) on June 13, 1892 [57]. Her father, Dr. Leopold Rotter, was a secondary school director. She attended elementary school and 1 year of the public school in Schönberg. When she was 11 years old, she arrived in Vienna and became a pupil at the Mädchengymnasium in Vienna VI., Hegelgasse 12 for 3 years. In July 1912, she passed the Matura examination at the Franz Josef Gymnasium in Schönberg and began to study at the University of Vienna in the following autumn. In 1913/1914, Rotter attended analytical chemical exercises at the Technische Hochschule under Prof. Georg Vortmann. On 1 January 1917, she became Prof. Schlenk's research assistant at the IInd Chemical Institute-and is hence considered to be the first female assistant at a Chemical Institute at the University of Vienna. "Über eine neue Synthese des Coniins und über einige andere mit Lithiumalkylen ausgeführte Synthesen" was the title of her doctoral thesis, which earned her a PhD on 21 July 1919. From the academic year 1920/1921-1927/28 she was assistant at the Ind Chemical Laboratory. Her field of research was the condensation of unsaturated compounds with diazomethane [58-60]. Since 1931/1932, she was listed as an extraordinary assistant at the Pharmacognostic Institute of the Faculty of Medicine. Apparently, she also completed a medical study, as her academic degree is listed as "Dr. phil. Dr. med." after WWII. In the early 1950s, she worked at the Federal Institute for Food Examinations in Vienna [61]. Gertrud Rotter died at the age of 80 in Vienna. She was buried at the Vienna Central Cemetery on 14 July 1972 (Gruppe 71B/17/16).

Celine (Celina) Bresiewicz came from Kalwarya in Galicia (today Kalwaria Zebrzydowska in Southern Poland). Her mother tongue was Polish, her religion Roman Catholic. At that time, her father, Dr. Thaddäus Bresiewicz (1862-1938), was judge at the County Law Court in Krakow. Later on, he became president of the Section Council at the Interior Ministry in Vienna [62]. In 1918, Celina Bresiewicz completed her studies at the University of Vienna with a dissertation "Über einige Derivate des Triphenylmethylnatriums". The subject clearly identifies her as a student of the chair of the IInd Chemical Institute in Vienna, Prof. Wilhelm Schlenk, who had been engaged in the study of organic radicals, in particular the triphenylmethyl radical. Prof. Schlenk published several results obtained by Celina Bresiewicz until 1928 [63].

Adele (Adela) Rothenberg (born in 1891 in Galicia) was also a student of Prof. Schlenk in Vienna. However, she obtained her doctorate only in 1920, which lies outside the observation period of this paper. Her career will be described in a subsequent publication. ${ }^{3}$

\section{Most of the theses of female chemists were published in the Chemical Monthly}

From the beginning, the results of the experimental work of the first female chemists in Austria were published in the most prominent Austrian chemical journal: the "Monatshefte für Chemie" (Chemical Monthly). We remember the 1901paper by Agnes Kelly and we remember Margarete Furcht's paper of 1902. The next publication by a woman appeared in this journal 3 years later:

Hedwig Stern, author of the paper [64] mentioned above, was born on 8 April 1880 as daughter of the Jewish houseowner Carl Stern (1845-1913) from Lundenburg in Southern Moravia (now Břeclav in the Czech Republic) and his wife,

\footnotetext{
${ }_{3}$ R.W. Soukup and J. Zachl, publication under preparation.
} 
Mathilde Stern, née Schwoner (1857-1923). Hedwig Stern's dissertation at the IInd Chemical Institute was supervised by Prof. Caesar Pomeranz (1860-1926), one of the discoverers of the Pomeranz-Fritsch reaction for the synthesis of isoquinoline. She received her PhD on 1 February 1906. In 1908, Hedwig Stern married the chemist Dr. Alfred Klüger, born in Vienna in 1882 [65]. Alfred Klüger had completed his studies at the same institute with a paper that was published in the same volume of the Monatshefte as his wife's [66]. Dr. Hedwig Klüger, née Stern died at the age of 57 on 24 June 1937 in Vienna.

In 1906, a paper by Hans Busch and Klara Goldenthal about the synthesis of formisobutyracetaldol was printed [67]. Klara (Clara) Goldenthal's Jewish family came from Zatkiew in Galicia. Like her fellow student Hedwig Stern, she finished her chemical studies at the IInd Chemical Institute of Prof. Adolf Lieben, and also acknowledged the kind support of Prof. Caesar Pomeranz. She graduated with a PhD on 6 July 1906.

In the same year, Berta Braun's thesis "Über die Einwirkung von Schwefelsäure auf die $\gamma$-Dimethyläthyl- $\beta$ oxybuttersäure"-also supervised by Caesar Pomeranzwas published, coauthored by the later well-known specialist for chemical coating Hans Kittel [68]. Berta was the daughter of a military officer from Korneuburg in Lower Austria. She was born in Korneuburg on 21 June 1880 and received her $\mathrm{PhD}$ on 15 March 1907.

Hedwig Feldscharek, born 25 September 1869, came to Vienna from Schönberg (today Šumperk) in Moravia, where her father was a railway official. She published her thesis "Über das Verhalten einiger Äthersäuren bei der Destillation" together with her academic supervisor Prof. Jacob Pollak (1872-1942) of the Ist Chemical Laboratory in 1908 [69]. In this paper, Pollak-a specialist for organic dyestuffs-and Feldscharek describe the migration of an alkyl group.

In the same volume of "Monatshefte", Marianne von Bronneck reports on the oxidation product of gallic acid [70]. The publication series on lactone dyes was initiated by Prof. Josef Herzig (1853-1924), one of the discoverers of the Herzig-Meyer reaction for the detection of methylimides. Herzig's student Marianne Goldreich Edle von Bronneck (married Kreidl) was born on 22 April 1885 in Prague. Her father was the lawyer Dr. Otto Goldreich Edler von Bronneck (1854-1913), and her grandfather the merchant and landowner Philip Goldreich von Bronneck (1812-1885). Her mother was Wilhelmine "Wilma" Pick (1865-1932), daughter of Lieutenant Colonel Ernst Pick (died in 1934) [71]. Marianne von Bronneck finished her chemical experiments at the Ist Chemical Institute in 1908 with her thesis "Studien über Laktonfarbstoffe".

Dr. Marianne von Bronneck married the engineer Alexander Kreidl (born in Prague on 22 May 1879), who owned several patents, partly together with his brother Ignaz. Alexander Kreidl died on 29 December 1937 in Vienna. After the occupation of Austria by Nazi Troops in March 1938, Dr. Marianne Kreidl was forced to immigrate to the USA. She moved to New York City and worked again as a scientist, now at the Madison Foundation for Biochemical Research New York. In 1953, "Marianne Kreidl PhD" together with the emigrated Austrian biochemist Rudolph Keller, and the American chemist Bernard Chiego published an article about a new cytological technique [72, 73]. Marianne Kreidl died at the age of 95 years on 9 September 1979 in Vienna and was buried at the Grinzing cemetery.

Another student of Prof. Josef Herzig was Margarete (Grete) Ruzicka (Ružička, married Viertel). Grete Ruzicka was born in 1888 in Pettau, Styria (today Ptuj, Slovenia). Her father was a Jewish merchant. In 1910, Margarete Ruzicka completed her studies at the Ist Chemical Institute with a dissertation "Über Galloflavin" and earned her doctoral degree on 18 July 1911. Prof. Herzig mentions "Experiments of Miss Grete Ruzicka" in his "VI. Communication on Galloflavin" [74]. The same year, now working as an actress, she met the dramaturg and later well-known stage-manager of the Viennese "Volksbühne", Berthold Viertel (1885-1953), whom she married in 1912 [75]. Six years later, they were divorced. The actress Salka Steuermann (1889-1978), who married Berthold Viertel a few weeks after the divorce, said about Dr. Grete Viertel that she was a pretty and intelligent woman, "though a little condescending" [76].

Stefanie Horovitz was born on 17 April 1887 in Warsaw. She was the daughter of the well-known Jewish painter Leopold Horovitz (1837-1917). She performed her organic chemistry experiments at the IInd Chemical Institute of the University of Vienna under Prof. Guido Goldschmiedt (1850-1915) and received her doctoral degree on 10 June 1914 [77], whereas two corresponding papers had already been printed in 1911 and 1912 [78, 79] (Fig. 4).

From 1914 to 1916, Stefanie Horovitz is listed in the annual reports of the "Radiuminstitut" as "working at the institute". There, Stefanie Horovitz determined the atomic weights of uranium, thorium, and ionium [80-83]. Due to her cooperation with Hönigschmid, Dr. Horovitz was involved in confirming Frederic Soddy's isotope theory.

During the interwar period, Horovitz worked-like Hilferding-Hönigsberg — at the Association for Individual Psychology. In 1924, she set up an education center for "difficult-to-educate and nervous" children, together with Alice Friedmann. The institution was shut down in 1934 by the Austro-fascist regime. In 1937, Stefanie Horovitz left Vienna, initially with an unknown destination. But now we know where she went. Her name is listed under "Horovitz Stefania" in the Yad Vashem database of Holocaust victims. It is stated that she was a chemist, living in Warsaw shortly before WWII. During the war she was forced to move to the 


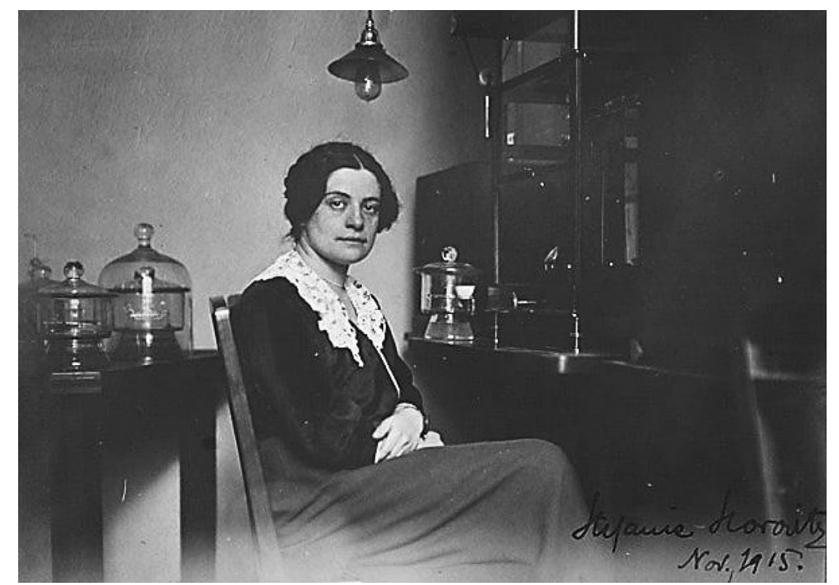

Fig. 4 Stefanie Horovitz at the "Wiener Radiuminstitut", November 1915. Photo: Zentralbibliothek für Physik, Wien. http://www.guten berg-e.org/rentetzi/detail/18-3.html. Accessed 2 April 2017

Warsaw Ghetto. From there she was deported to the Treblinka Concentration Camp, where she was murdered in a gas chamber in 1942 .

A pioneering result in physiological chemistry was achieved at the IInd Chemical Institute by Rudolfine Waltuch (married Wenzel) and her chemical supervisor Ernst Zerner. Rudolfine Waltuch was born on 1 March 1891 in Vienna as daughter of the wealthy Jewish stock exchange agent Josef (Hersch) Waltuch (born 1859 in Husyatyn, died 1944 in New York) and his wife Ernestine (Ester) Waltuch (née Baar 1861-1895) [84]. Already in her school days, she was introduced to the idea of Zionism, and one of her teachers, with whom she stayed in close contact throughout her life, was Leopoldine Glöckel-wife of the school reformer Otto Glöckel. Rudolfine Waltuch earned her PhD in 1914 with the thesis "Über Charakterisierung der Harnpentose". Importantly, a paper describing her studies on this interesting sugar had already been published 1 year before [85]. Subsequently, Rudolfine Waltuch and Ernst Zerner succeeded in identifying the nsaid pentose found in the urine of patients suffering from the rare metabolic disease pentosuria as "l-ketoxylose" [86, 87] (Fig. 5). ${ }^{4}$

In 1915, Rudolfine Waltuch married the physician Dr. Rudolf Menzel, and as of 1920 Rudolfine Menzel began breeding and training boxer dogs. Over the following years, the couple Menzel published numerous articles in international cynological journals. Rudolfine Menzel undertook two trips to Palestine in the early 1930s. Following the events of March 1938, the contacts she established there enabled

\footnotetext{
${ }^{4}$ L-Ketoxylose was found also in 1914 by Levene and La Forge in the course of pentosuria. In 1936, Levene und Tipson proposed the name "L-Xylulose" [88, 89].
}

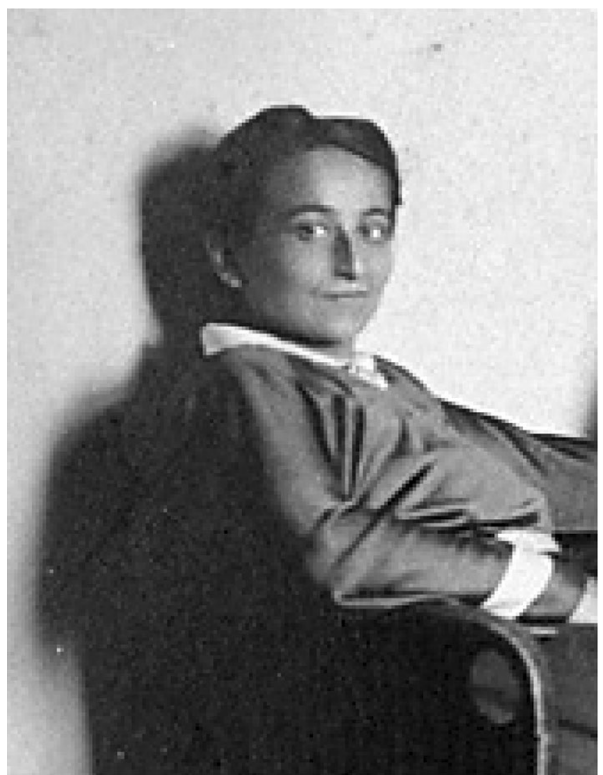

Fig. 5 Rudolfine Menzel, née. Waltuch, ca. 1920, Center for Jewish History NYC. https://www.flickr.com/photos/center_for_jewish_histo ry/4923932610/in/photostream/. Accessed 15 April 2017

the couple to flee to Palestine. There and-later on-in the newly founded state of Israel, Rudolfine Menzel continued to work in dog breeding and was also active in journalism. Rudolf and Rudolfine Menzel founded the "Canine Research and Training Institution" in Kiryat Motzkin, where they trained guide dogs, but also mine search dogs. They found out that wild dogs-so-called pariah dogs-were very docile [90]. From 1962 onward, Rudolfine Menzel taught as a professor of animal psychology at the University of Tel Aviv. She died in September 1973 in Haifa. In February 2016, an alley in Linz-Pichling was named after her [91]. The legacy of Rudolfine Menzel can be found in the Central Zionist Archive in Jerusalem (A293). Autobiographical notes are entitled "My Life in Germany" [92].

A considerable number of female chemists were interested in physiological chemistry, e.g., Maria Mauthner. Maria Mauthner was born on 20 April 1886 in Vienna. Her "Matura" certificate is dated 8 July 1907. After experimental studies at the Physiologic Institute of the University of Vienna under Prof. Otto von Fürth (1867-1938), she received her $\mathrm{PhD}$ in 1913. Her experimental results regarding the carnosine content of mammalian muscles were published in 1913 [93].

In 1914, Hildegard(e) Nowak published a paper about a condensation product of benzaldehyde [94]. Aldehyde condensation had been the last field of research of the great doyen of organic chemistry in Vienna Prof. Adolf Lieben (1836-1914), who died in this very year. Hildegard(e) Nowak was born on 22 September 1889 in Vienna, but her 
mother tongue was Polish. Her academic supervisor was Prof. Guido Goldschmiedt.

Finding information about the private life and career of the next woman chemist proved to be especially challenging: Alice (Anna) Joachimowitz, née Wolf finished two studies at the University of Vienna. She was born on 19 August 1890 in Linz, Upper Austria. Her father was a Jewish leather goods retailer. Alice (Anna) Wolf first studied botany and completed her botanical studies with the thesis "Über ein fossile Taxodium aus dem niederösterreichisch-ungarischen Grenzgebiet" in 1911. Thereafter, she started her chemical studies. The title of her chemical dissertation was "Über Phenylthioglykol-o-karbonsäure, ihr Methylester und deren Verseifung". The results of this work were published in 1914 [95]. The date of her graduation is 28 June 1916, after which she began working as a chemist. Her improvements of the Kjeldahl method were published in the widely recognized "Chemiker-Zeitung" in 1917 [96]. In 1919, "Wolf-Joachimowitz, Alice, Dr., Chemikerin, Wien XVI., Ottakringerstraße 129" was supporting member of the "Verein zur Verbreitung naturwissenschaftlicher Kenntnisse" [97]. In that year, she was affiliated with the "Philipp Röder-Bruno Raabe-Aktiengesellschaft" with regard to a patent (Ö.P. 81230). The next year, Alice Wolf-Joachimowitz received a similar patent (Ö.P. 99670) for the Pharmazeutische Industrie A.G.

At present, the family connections of Alice Wolf-Joachimowitz are under investigation. It is not proved, but it is probable that she married the physician Robert Joachimowitz (born in 1892, Prof. in 1945), who became lecturer of gynecology and obstetrics in 1930 and was dismissed by the Nazi regime in 1938 [98].

In 1916, Josef Herzig and his assistant Franz Wenzel (born in 1872) mention experiments performed by Miss Stephanie Eberwein in a paper printed in the Chemistry Monthly [99]. Stephanie Eberwein was indeed a student of Herzig at the Ist Chemical Institute. Eberwein's thesis, submitted in 1913, was entitled "Zur Konstitution des Paramethylorcins". Stephanie Eberwein was born in Suszawa in Bukovina (today Suceava, Romania) on 25 April 1885. She earned her doctorate on 3 December 1915.

In 1913, Adele (Adela) Baar had finished her theses studies "Zur Verseifung von Dimethylsulfat und Diäthylsulfat in Lösungen”. In the corresponding paper, which was published in the "Monatshefte" 4 years later, the authors Jacob Pollak and Adele Baar point out that the reasons for the delay in publication were of purely external character [100]. Adele Baar was Jewish. She came from Jagielnica in Galicia (today in Ukraine), where she was born 2 January 1888. Her father was the owner of a brewery. Her graduation certificate is dated 3 December 1915.

Alfons Klemenc (1885-1960), at that time Privatdozent at the University Vienna, mentions his coworker
Emma Edhofer in the headline of a paper from 1917 in the "Monatshefte für Chemie" [101]. Emma Edhofer (married Ringel) was born in Weidling am Bach on 2 March 1895, as the daughter of a Viennese hotel owner. In 1919, her thesis "Über das Gleichgewicht der Salpetersäure" was approved. One year later she married the Austrian military officer Julius Ringel (1889-1967) and became a housewife.

Gertrud Tiring (married Schwarzmann) was born on 1 January 1892 in Vienna. She was the daughter of the Jewish merchant Conrad Tiring (1861-1942) and of Irene Tiring, née Kohnberger (1868-1942 or 1943). Her father came from Constantinople, her mother from Vienna. Both parents were deported to the Theresienstadt Concentration Camp in 1942, where they were murdered [102].

Gertrud Tiring wrote her dissertation "Zur Kenntnis des Skoparins" at the Ist Chemical Institute in 1917. She published the results of this work together with her doctoral supervisor Josef Herzig 1 year later [103]. In 1917, she married Emil Schwarzmann, who was born on 2 August 1885 in Izmir. With Dr. Schwarzmann she had three children: Annelise, Marguerite, and Peter [104]. Gertrud Schwarzmann later immigrated to the USA [105]. Her name and the name of her spouse appear in the US Federal Census for 1940: place of residence "New York Assembly District 23, Manhattan". Moreover, her husband's profession is listed as surgeon and "private doctor" [106].

It is remarkable that in the last year of WWI, a lot of papers written (or coauthored) by women appeared in the "Monatshefte für Chemie". An example is a paper by Jacque Pollak, Luzie von Fiedler, and Heinrich Roth [107]. Jacob (Jacque) Pollak (born in Budapest 1872, died in KZ Theresienstadt 1942) was at that time Professor at the Ist Chemical Institute, Heinrich Roth (born in 1888) and Luzie von Fiedler were his doctoral candidates. Luzie (Lucia) von Fiedler came from Krakow. She was the daughter of Colonel Heinrich Freiherr von Fiedler (1856-1932), Commander in Chief of the k.u.k Schlesisches Infanterieregiment "Kaiser Nr.1" in Troppau (Opava). After ten semesters she finished her studies with the thesis "Über Halogensubstituierte mehrwertige Mercaptane der Benzolreihe" in 1915.

Like Luzie von Fiedler, her companion at the Ist Chemical Institute Elisabeth Ekl was born in one of the Crown Lands of the Habsburg Monarchy. Elisabeth (Else) Ekl (married Lant) was born in Ljubljana on 17 February 1893. Her father Karl Ekl was judge at the Regional Court of Krain, Cilli and Marburg, and later President of the Senate in Vienna. In 1918, she finished her thesis "Über die Messung der Nitrierungsgeschwindigkeit von Phenolen in Äther". She earned her PhD on 8 July 1918. Dozent Alfons Klemenc, who was also from Ljubljana, published this work together with her in the "Monatshefte für Chemie" in the same year [108]. 
From October until the end of December 1918, "Fräulein Dr. Ekl" was employed as research assistant of Prof. Max Bamberger (1861-1927) at the Laboratory of Inorganic Chemistry and Encyclopedia of Technical Chemistry at the "Technische Hochschule". Because this position was originally reserved for a war veteran (Dr. Foltz), she was discharged [109]. In the following months, she analyzed Austrian clays in the following months to find a surrogate for soap—without any remuneration [110]. From February to May 1920, Dr. Else Ekl was chief chemist at the private laboratory of Drs. Stockert and Trakl. In May 1920, she became assistant of Prof. Hugo Strache (1865-1927) at the "Research Institute for Fuels, Furnaces and Gas Lighting". So, Dr. Elisabeth Lant, née Ekl was the first female (research) assistant at the "Technische Hochschule". At her institute, she became familiar with Richard Lant (born as Lewith in 1896, change of name in 1918). The couple married in 1921. Together with her husband, she published an often-cited paper in the journal "Brennstoffchemie" [111]. In 1923, Richard and Elisabeth Lant terminated their job at the "Technische Hochschule". On 24 March 1925, their son Rainer Maria Carl was born. After the occupation in 1938, they immigrated to Great Britain. In 1939, she lived together with her husband—now a consulting chemist—and her son in Harrow, Middlesex, England (Somerley House) as a housewife [112]. Sie died in December 1976 in Hendon (Greater London).

A fellow student of Elisabeth Ekl was Cäcilie Ripper. Cäcilie (Lilly) Ripper (née Glaser), born on 8 November 1893 in Vienna, earned her PhD on 8 July 1918. The experiments for her thesis "Verseifung von Essigsäureäthylester mit alkoholischer Natronlauge" were performed at the Ist Chemical Institute under the supervision of Prof. Rudolf Wegscheider [113].

Already during her university study, Lilly Ripper was teaching inorganic and organic chemistry at the "Wiener Handelsakademie für Mädchen" [114]. In 1925, she was the first female patent attorney in Austria (Fig. 6). Seven years later, she not only attended the Congress of the "Association Internationale pour la Protection de la Propriété Industrielle" (in London), but made valuable proposals there.

A further female student of Prof. Wegscheider was Helene Schreiner. Helene Schreiner was born in Vienna on 15 May 1893. Her father was a publisher's reader. She began her studies in 1914 and received her doctoral degree in 1919. The results of her thesis, "Über Sulfoniumverbindungen", were published in the same year [115]. Apart from her main occupation at the "Allgemeine Poliklinik", Helene Schreiner became an assistant of Richard Teschner at Teschner's wellknown puppet theater.

A different "Monatshefte" paper from 1919 describes the preparation of double halogenides of trimethylsulfonium compounds with some metal cations [116]. The affiliation of

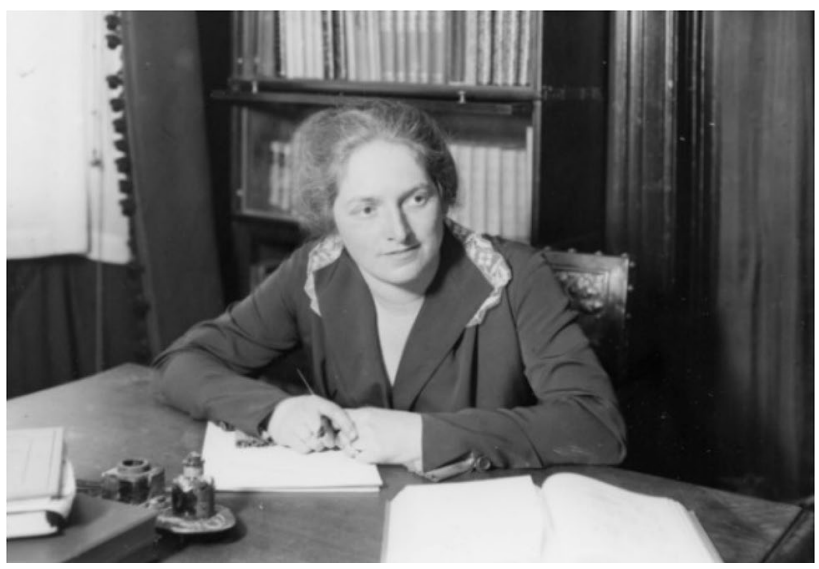

Fig. 6 Dr. Cäcilie Ripper, ca. 1928, Bildarchiv ÖNB, Inventarnummer A 302. http://www.bildarchivaustria.at/Preview/2937686.jpg. Accessed 2 November 2018

the author Hildegard Blättler was the "I. Chemische Laboratorium der Universität Wien", her nationality was Swiss, but her birthplace was Brünn (Brno) in Moravia (date of birth: 8 July 1896). Her thesis "Über Trimethylsulfoniumverbindungen" earned her a PhD on 12 December 1919.

On the same day as Hildegard Blättler, Hedwig Ortony received her doctoral degree. Hedwig Ortony was born on 6 October 1894 as daughter of Sigmund Ortony (Ochs 1863-1942) and Marianne Ortony (née Neustadtl 1872-1942) in Vienna [117]. Her thesis was entitled "Über die Methylierung einiger bis jetzt nicht methylierbarer Stoffe". She published important results of her work together with Prof. Josef Herzig in 1920 [118]. After having left the university, she worked as a pharmacist in Vienna. On April 27, 1942 — only a few days after the burial of her fathershe was deported to the Włodawa Concentration Camp near Lublin. There, or more probably in the nearby extermination camp Sobibór, she was murdered.

\section{Conclusion}

How many women earned a PhD until 1919 and worked as chemists (or pharmacologists) for more than a few years after their graduation? The answer is nine. An additional six women worked at least a few years as chemists. Four women are known for a completely different career: as we have seen, Stefanie Horovitz became an educator; Lily Bader, née Stern, a piano teacher; Rudolfine Wenzel (née Waltuch) became professor for animal psychology in Israel; and Grete Viertel, née Ruzicka, became an actress. We know without doubt of five women who stopped doing any scientific work after marriage, and we guess that the number of housewives is much higher. 
But what happened to the Jewish women? Seven of them managed to emigrate, and four of them were murdered in the Holocaust. So, about $28 \%$ of the women under consideration had to flee or were murdered-an incredibly high number! Moreover, we are not sure whether the total number may be even higher, as we have no idea what happened to the second half of the women. ${ }^{5}$

To sum up, the result is daunting or even frightening. The way the first female chemists in Austria had to go was a very stony one-and in some cases it ended in a gas chamber. It took quite a long time before the first women achieved academic leadership positions in chemistry. In 1940, Margarete (Rita) Garzuly-Janke habilitated at the "Technische Hochschule" in Vienna. At the University of Vienna, Dr. Nelly Konopik (married Brinda-Konopik) became "Universitätsdozent für spezielle physikalische Chemie" in 1975. Finally, the first woman on a chemistry chair at the University of Vienna was Annette Rompel only in 2008.

Acknowledgements Open access funding provided by University of Vienna. Valuable hints from two referees are acknowledged by the authors. Special thanks are due to Dr. Klara Soukup for proofreading.

Open Access This article is distributed under the terms of the Creative Commons Attribution 4.0 International License (http://creativeco mmons.org/licenses/by/4.0/), which permits unrestricted use, distribution, and reproduction in any medium, provided you give appropriate credit to the original author(s) and the source, provide a link to the Creative Commons license, and indicate if changes were made.

\section{References}

1. Kritscher H, Szilvássy J, Vycudilik W (1994) Mitt Ges Salzburger Landeskd 14:94

2. Reiter C (1994) Mitt Ges Salzburger Landeskunde 14:114

3. Mikoletzky J, Georgeacopol-Winischhofer U, Pohl M (1997) "Dem Zuge der Zeit entsprechend..." Zur Geschichte des Frauenstudiums in Österreich am Beispiel der Technischen Universität Wien. WUV-Universitätsverlag, Wien, pp 22-25

4. Cornish-Bowden A (1999) The Biochemist 19:36

5. Fischer M (2013) Lebendige Verbindungen. Biobibliographisches Lexikon der Biochemiker zwischen Deutschland und Russland im 19. Jahrhundert. Shaker, Aachen, 113. Манасеина, Марья Михайловна. http://drw.saw-leipzig.de/31160 Accessed 30 June 2018

6. Манасеина М (1871) Predvar. Medicinskij vestnik 8:57

7. Манасеина M (1871) Voenno Med Ž 8:155

\footnotetext{
5 As it is the case with Ida Edle von Metz (born 7 July 1880 in Graz, Dr. 1905), Dora Hof(f)mann (born 12 September 1884 in Vienna, Dr. 1908), Maria Bayer (born 16 July 1887 in Bochina, Galicia, Dr. 1913), Elisabeth Eiveling (Eiweling, Eyweling) (born 21 February 1891 in Suczowa (Suceava), Bukovina, Dr. 1915), Auguste Kichler (born 28 June 1892 in Hainfeld in Lower Austria, Dr. 1916), Regina Meller (born 25 August 1893 in Zurawno (Schurawno), Galicia, Dr. 1917), Maria Buckwitz (born 9 July 1890 in Vienna, Dr. 1918), Paula Fried (born 11 June 1894 in Fulnek, Moravia, Dr. 1919).
}

8. Manassein M (1872) In: Julius Wiesner (ed), Mikroskopische Untersuchungen. Ausgeführt im Laboratorium für Mikroskopie und technische Waarenkunde am k. k. polytechnischen Institute in Wien. Stuttgart, p 116

9. von Manasseïn M (1897) Ber Dtsch Chem Ges 30:3061

10. von Manasseïn M (1898) Le Physiol Russe 1:88

11. Barnett JA, Barnett L (2011) Yeast research: a historical overview. American Society for Microbiology Press, Washington

12. Wien Geschichte Wiki (2018) Frauenstudium, Stadt Wien. https ://www.geschichtewiki.wien.gv.at/Frauenstudium. Accessed 30 October 2018

13. Seebacher F (2008) IKW-Mitteilungen $1 / 2: 52$

14. Schuster E (1996) In: Kernbauer A, Schmidlechner-Lienhart E (eds) Frauenstudium und Frauenkarrieren an der Universität Graz. Akademische Druck- u. Verlagsanstalt, Graz, p 25

15. List E (2006) Mutterliebe und Geburtenkontrolle-Zwischen Psychoanalyse und Sozialismus. Die Geschichte der Margarethe Hilferding-Hönigsberg. Mandelbaum Verlag, Wien

16. Terezinska Pametni Kniha, Terezinska Iniciativa, Melantrich, Praha 1995. http://yvng.yadvashem.org/nameDetails.html?langu age $=$ de \&itemId $=4743459 \&$ ind $=0$. Accessed 2 August 2017

17. Herklots J (2015) Agnes Murgoci. 1874-1929 https://rshg.org. uk/wp-content/uploads/2015/08/MURGOCIAgnes7.5.1929.pdf. Accessed 2 March 2018

18. Fränkel S, Kelly A (1902) Monatsh Chem 23:123

19. Bischof B (2008) IKW-Mitteilungen 1/2:6

20. Wegscheider R, Furcht M (1902) Monatsh Chem 23:1093

21. Furcht M, Lieben A (1909) Monatsh Chem 30:555

22. Bischof B (2018) In: Korotin Ilse, Stupnicki Nastasja (eds) Biografien bedeutender österreichischer Wissenschafterinnen. Böhlau Verlag, Wien, p 264

23. Rosner R (2012) Mitt Österr Ges Wiss 29:133

24. Rosner R (2017) Frauen in den Naturwissenschaften: die ersten Absolventinnen an der Universität Wien (1900-1919). http:// scienceblog.at/book/export/html/877\#.W0s2Mj9DvIU. Accessed 15 July 2018

25. Archive of the University of Vienna, Rigorosenakten der Philosophischen Fakultät. http://scopeq.cc.univie.ac.at/Query/detai 1.aspx?ID=234722. Accessed 17 July 2018 until 15 January 2019

26. Rosner RW (2015) Mädchenmittelschulen zur Jahrhundertwende von Lemberg bis Innsbruck. Frauenbildung für den "Five o'clock tea" oder für die Uni. https://schulmuseum.schule.wien.at/filea dmin/s/111111/Dateien/Zeitungsartikel/Rosner_M\%C3\%A4dch enB_LangF_WSM-2015-1_2.pdf. Accessed 15 July 2018

27. Franke A, Lieben F (1922) Monatsh Chem 43:225

28. Obituary 1 (1964) New York Times, August 14th, 1964, p 27. http://www.nytimes.com/1964/08/14/obituary-1-no-title.html? $\mathrm{r}=0$. Accessed 30 October 2018

29. Feigl F, Stern R (1921) Z Anal Chem 60:1

30. Kretzschmar H (1955) Hefe und Alkohol sowie andere Gärungsprodukte. Springer, Berlin, p 341

31. ÖStA, AdR, Finanzen, VVSt., VA 3451, 28.06.1938, Dr. Rosa Stern. Cited after: Kern A (2012) Arisierte Patente. Jüdische ErfinderInnenschicksale im Nationalsozialismus. Diplomarbeit, Universität Wien, p 61. http://othes.univie.ac.at/26117/1/201212-15_0701537.pdf. Accessed 8 July 2018

32. Franke A, Stern R (1928) Monatsh Chem 49:21

33. AJR Informations XLVI/1 (1991) p 15: https://ajr.org.uk/wpcontent/uploads/2018/02/1991_january.pdf. Accessed 8 July 2018

34. Bader LM (1956) One Life is not Enough, Leo Baeck Institute, LBI Archives, LBI Memoir Collection, ME 784

35. Bader L (2011) Ein Leben ist nicht genug. Memoiren einer Wiener Jüdin. Milena Verlag, Wien

36. Korotin I (2016) biografiA. Lexikon Österreichischer Frauen, vol 1. Böhlau, Wien, p 182 
37. Österreichisches Staatsarchiv/Archiv der Republik, Wien: Vermögens-anmeldungen 1938 von Edwin und Lily Bader (Sign.: AT-OeStA/AdR E-uReang VVSt VA Buchstabe B 43.171, ATOeStA/AdR E-uReang VVSt VA Buchstabe B 43.170; Sign.: AT-OeStA/AdR E-uReang AHF B Bader, Edwin, Nr. 16.232)

38. Whiteman DB (1995) Die Entwurzelten. Jüdische Lebensgeschichten nach der Flucht 1933 bis heute. Böhlau-Verlag, Wien

39. Documents of Lily Bader (née Stern) (2007) Karton Nr. 40, Sign 144. http://www.injoest.ac.at/files/namensliste.pdf. Accessed 8 July 2018

40. Kniefacz K (2018) In: Gedenkbuch für die Opfer des Nationalsozialismus an der Universität Wien 1938. Guide to the Stern'sche Mädchen- Lehr- und Erziehungsanstalt Collection. http://digit al.cjh.org/view/action/singleViewer.do?dvs $=1493575503$ 284 137\&locale=de_AT\&VIEWER_URL=/view/action/singl eViewer.do?\&DELIVERY_RULE_ID $=6 \&$ frameId=1\&usePi $\mathrm{d} 1=$ true \&usePid2 =true. Accessed July 8, 2018

41. Claims Resolution Tribunal (2013) Holocaust Victim Assets Litigation, Case No. CV96-4849, Accounts of Lily Bader, Österreichische Parlamentsbibliothek (2013) Regine Stern and Hilda Pollak. http://www.provenienzforschung.gv.at/wp-content/uploa ds/2014/04/Parlamentsbibliothek_2013-06-21.pdf. Accessed 2 November 2018

42. Lichtblau A (1999) Als hätten wir dazugehört: österreichischjüdische Lebensgeschichten aus der Habsburgermonarchie. Böhlau-Verlag, Wien, p 545

43. Österreichisches Staatsarchiv/Archiv der Republik, Sign. ATOeStA/AdR E-uReang VVSt VA Buchstabe B 43.171, ATOeStA/AdR E-uReang VVSt VA Buchstabe B 43.170; Sign. AT-OeStA/AdR E-uReang AHF B Bader, Edwin, Nr. 16.232

44. Cornelius M, Fraenkel S (1918) Ber Dtsch Chem Ges 51:1654

45. Aliza Beserglik Fodor (1999) Central Database of Shoah Victims' Names. http://yvng.yadvashem.org/index.html?langu age $=$ de \&s_lastName $=$ Cornelius\&s_firstName=Martha\&s_place . Accessed 2 November 2018

46. Kopetschni E, Larczag L, Fodor O, Fodor S (1913) Anhydride of salicylic acid and process of preparing the same. US Patent 1075581; (1914) Chem Abstr 8:7911

47. Central Database of Shoah Victims' Names (2018). https://yvng. yadvashem.org/nameDetails.html?language $=$ en $\&$ itemId $=10488$ 90. Accessed 01 November 2018

48. Möller K (2014) Stolpersteine Hamburg. Dr. Katharina Leipelt. http://www.stolpersteine-hamburg.de/?MAIN_ID=7\&BIO_ $\mathrm{ID}=230$. Accessed 29 November 2018

49. Findagrave (2018). http://www.stolpersteine-hambu rg.de/?MAIN_ID=7\&BIO_ID=230. Accessed 30 October 2018

50. Herzig J, Landsteiner K (1918) Monatsh Chem 39:269

51. Hitzenberger K, Richter-Quittner M (1921) Wiener Arch Inn Med 2:461

52. Depisch F, Richter-Quittner M (1921) Wiener Z Inn Med 5:321

53. Richter-Quittner M (1925) Z Ges Exp Med 45:479

54. Geni (2018) Obituary. https://www.geni.com/people/Dr-Maria nne-Richter/6000000019374167284 (The date of birth is erroneous!) Accessed 14 July 2018

55. von Wretschko AR (1905) Ernst Demelius. Wagnersche Buchhandlung, Innsbruck

56. Index of botanists (2018) Harvard University Herbaria \& Libraries. http://kiki.huh.harvard.edu/databases/botanist_searc h.php?mode $=$ details $\& i d=66930$. Accessed 2 November 2018

57. Korotin I, Stupnicki N (eds) (2018) Biografien bedeutender österreichischer Wissenschafterinnen. Böhlau, Vienna, p 727

58. Rotter R (1926) Monatsh Chem 47:353

59. Rotter R, Mitbearbeitet von Elsa Schaudy (1926) Monatsh Chem 47:493

60. Rotter R, Schaudy E (1931) Monatsh Chem 58:245
61. Rotter R (1952) Z Lebensmittel-Untersuchung und Forschung 95:89

62. Mischler E, Ulbrich J (1907) Österreichisches Staatswörterbuch: Handbuch des gesamten österreichischen öffentlichen Rechtes, vol 3. Hölder, Wien, p 742

63. Schlenk W, Bergmann E, Mitbearbeitet von Celina Bresiewicz (1928) Liebigs Ann Chem 463:2871

64. Stern H (1905) Monatsh Chem 26:1559

65. Geni (2018). https://www.geni.com/people/Hedwi g-K1\%C3\%BCger/6000000033691923932. Accessed 30 October 2018

66. Klüger A (1905) Monatsh Chem 26:879

67. Busch H, Goldenthal K (1906) Monatsh Chem 27:1157

68. Braun B, Kittel H (1906) Monatsh Chem 27:803

69. Pollak J, Feldscharek H (1908) Monatsh Chem 29:139

70. von Bronneck M (1908) Monatsh Chem 29:289

71. Antientfaces (2018) http://www.ancientfaces.com/surname/kreid 1-family-history/403122. Accessed 30 October 2018

72. Kreidl M, Keller R, Chiego B (1953) Cytologia 18:322

73. Neuberg C, Grauer A, Kreidl M, Lowy H (1957) Arch Biochem Biophys 70:70

74. Herzig J (1910) Monatsh Chem 31:799

75. Heuer R (2012) Lexikon deutsch jüdischer Autoren, vol 20. De Gruyter, Berlin and Boston, p 176

76. Nijssen HMAJ (1995) Der heimliche König: Leben und Werk von Peter Huchel. Nijmegen, p 50

77. Archivinformationssystem (2018) Universität Wien. https://scope q.cc.univie.ac.at/Query/detail.aspx ?ID=211118. Accessed 29 October 2018

78. Böttcher B, Horovitz S (1911) Monatsh Chem 32:793

79. Böttcher B, Horovitz S (1912) Monatsh Chem 33:567

80. Hönigschmid O, Horovitz S (1914) Monatsh Chem 35:1557

81. Hönigschmid O, Horovitz S (1915) Monatsh Chem 36:355

82. Hönigschmid O, Horovitz S (1916) Monatsh Chem 37:305

83. Hönigschmid O, Horovitz S (1916) Monatsh Chem 37:335

84. Geni (2017) "Obituary Ernestine Waltuch, geb. Baar". https:// www.geni.com/people/Esther-Ernestine-Waltuch/6000000030 453146267. Accessed 17 April 2017

85. Zerner E, Waltuch R (1913) Monatsh Chem 34:1639

86. Zerner E, Waltuch R (1914) Biochem Z 58:410

87. Zerner E, Waltuch R (1914) Monatsh Chem 35:1025

88. Levene PA, La Forge FB (1914) J Biol Chem 18:319

89. Levene PA, Tipson RS (1936) J Biol Chem 116:731

90. Räber H (2014) Enzyklopädie der Rassehunde, vol 1. Stuttgart, p 626

91. Die Presse (2017) Press release 2.4.2016. http://www.linz.at/ presse/2016/201602_81852.asp. Accessed 14 April 2017

92. Houghton Library, Harvard University, Boston bMSGer91, 155

93. Mauthner M (1913) Monatsh Chem 34:883

94. Nowak H (1914) Monatsh Chem 35:909

95. Wegscheider R, Joachimowitz A (1914) Monatsh Chem 35:1037

96. Wolf-Joachimowitz A (1917) Chem Ztg 41:87

97. Jahresbericht (1919) http://www.zobodat.at/pdf/SVVNW K_59_V-XLVII.pdf. Accessed 18 July 2018

98. Koren N (1973) Jewish Physicians. Israel University Press, Jerusalem, p 198

99. Herzig J, Wenzel F (1916) Monatsh Chem 378:549

100. Pollak J, Baar A (1917) Monatsh Chem 38:501

101. Klemenc A (1917) Monatsh Chem 38:553

102. Central Database of Shoah Victims' Names (2018) http://yvng. yadvashem.org/index.html?language $=$ en\&s_lastName $=$ Tirin g\&s_firstName $=\&$ s_place $=$. Accessed 18 July 2018

103. Herzig J, Tiring G (1918) Monatsh Chem 39:253

104. Geni (2018) https://www.geni.com/people/Peter-Schwarzman n/6000000025099631766. Accessed 2 November 2018 
105. Gersuny Family Collection (2017) AR 7271 F AR 7271, Center for Jewish History, New York: Six daughters of Solomon and Emilie Kohnberger. http://digital.cjh.org/R/B6RGG25Y6C LUCMFEN43DQANUMPUV558B3NGA6YTF1PATIKHTUJ -01399 ? func $=$ dbin-jump-full\&object $\% 5$ Fid $=1027200 \&$ local $\% 5$ Fbase $=$ GEN01\&pds_handle=GUEST. Accessed 25 April 2017

106. National Archives, Records of the Property Control Branch of the U.S. Allied Commission for Austria 1945-1950, Disk 237 Correspondence Relate to Claims and Queries 1945-1950 A 584 "Gertrude Tiring-Schwarzmann". https://www.archives.gov/files /research/microfilm/dn1929.pdf. Accessed 25 April 2017

107. Pollak L, von Fiedler L, Roth H (1918) Monatsh Chem 39:179

108. Klemenc A, Ek1 E (1918) Monatsh Chem 39:641

109. Archive of the Technical University Vienna, Personal record of Elisabeth Lant-Ekl 769

110. Weißenberger G (1920) Kolloid-Z 27:70

111. Lant R, Lant-Ekl E (1921) Brennstoffchemie 2:330

112. England and Wales Register for Richard Lant (1939) The National Archives, Kew, London, England: https://searc h. ancestry.com/cgi-bin/sse.dll?indiv $=1 \& d b=1939$ U KRegi ster\&h=10389208. Accessed 28 June 2018

113. Wegscheider R, Ripper L (1918) Monatsh Chem 39:325

114. Austrian National Library (2016) Frauen in Bewegung: 18481938. http://www.fraueninbewegung.onb.ac.at/Pages/Historisch eEreignisseDetails.aspx?p_sYear=1918. Accessed 6 June 2018

115. Wegscheider R, Schreiner H (1919) Monatsh Chem 40:325

116. Blättler H (1919) Monatsh Chem 40:417

117. Geni (2019) http://www.geni.com/people/Hedwig-Ortony/60000 00020146475169. Accessed 13 January 2019

118. Herzig J, Ortony H (1920) Arch Pharm 258:91

Publisher's Note Springer Nature remains neutral with regard to jurisdictional claims in published maps and institutional affiliations. 